\title{
Tuturan Bahasa Indonesia Masyarakat Etnik Keturunan Arab Di Kota Bangil
}

\author{
Wegig Panji Prasasti $a, 1^{*}$ \\ aYAIKA BangiL, Jalan Bader 9 Kalirejo Bangil, Pasuruan, 67153, Indonesia \\ ${ }^{1}$ wegigprasasti92@gmail.com
}

*Corresponding Author

\begin{tabular}{l} 
INFO ARTIKEL \\
\hline Sejarah Artikel: \\
Diterima: 30 September \\
2020 \\
Direvisi: 15 Oktober \\
2020 \\
Disetujui: 1 November \\
2020 \\
Tersedia Daring: 16 \\
November 2020 \\
\hline
\end{tabular}

Kata Kunci:

Alih Kode

Etnik Arab

Campur Kode

Tuturan

\begin{abstract}
ABSTRAK
Bahasa dapat mengidentifikasi seseorang dari mana mereka berasal melalui tuturan yang mereka ujarkan. Melalui tindak tutur kita dapat mengetahui asal daerah seseorang. Tindak tutur merupakan gejala individual, bersifat psikologis, dan keberlangsungannya ditentukan oleh kemampuan bahasa si penutur dalam menghadapi situasi tertentu. Dalam hal ini, tuturan yang diujarkan oleh seseorang yang berasal dari keturunan etnik Arab berbeda dengan tuturan masyarakat kota Bangil pada umumnya. Tuturan mereka dipengaruhi oleh aksen dan beberapa kata dalam bahasa Arab yang masih mereka gunakan atau dapat disebut dengan peristiwa campur kode. Penelitian ini bertujuan untuk mengetahui tuturan yang digunakan oleh masyarakat etnik keturunan Arab di kota Bangil. Adapun pendekatan yang digunakan dalam penelitian ini adalah pendekatan kualitatif dengan metode penelitian etnografi. Masyarakat keturunan etnik Arab umumnya tergolong masyarakat dwibahasa. Mereka menguasai bahasa pertama (B1) bahasa daerah dan bahasa kedua (B2) bahasa Arab. Ragam yang dimaksud dalam penelitian ini adalah suasana maupun gaya bahasa yang terjadi ketika suatu peristiwa tutur berlangsung. Pada penelitian ini, ragam bahasa yang digunakan ketika terjadi peralihan kode dari BI ke BA adalah dua tuturan dalam ragam resmi. Pada penelitian ini, peralihan kode BI ke BA dalam ragam resmi terdapat dua tuturan, yaitu tuturan yang diberi nomor (1) dan (2). Kontak yang intensif antara dua bahasa atau lebih di dalam situasi yang memiliki lingkungan dwibahasa seperti halnya di masyarakat Indonesia dan dalam kasus ini adalah Kota Bangil dapat menimbulkan alih kode dan campur kode. Dalam penelitian tersebut dapat disimpulkan bahwa pada tuturan masyarakat etnik keturunan Arab sering melakukan alih kode dan campur kode.
\end{abstract}

\begin{tabular}{ll}
\hline ABSTRACT \\
\hline Keywords: & Language can identify a person where they come from through the speech \\
Arab Ethnic & they speak. Through speech acts we can find out where someone is from. \\
Mixed Code & Speech act is an individual symptom, psychological in nature, and its \\
Speech & continuity is determined by the speaker's language ability in dealing with \\
& certain situations. In this case, the speech uttered by someone who comes \\
& from Arab ethnic descent is different from the speech of the people of \\
& Bangil city in general. Their speech is influenced by accents and some \\
Arabic words that they still use or can be called code-mixed events. This \\
study aims to determine the utterances used by ethnic Arab descendants \\
in the city of Bangil. The approach used in this research is a qualitative \\
approach with ethnographic research methods. People of Arab ethnic \\
descent are generally bilingual. They master the first language (B1) \\
regional language and second language (B2) Arabic. The variety referred \\
to in this study is the atmosphere and language style that occurs when a \\
speech event takes place. In this study, the variety of languages used when \\
there was a code transition from BI to BA were two speeches in official
\end{tabular}


types. In this study, the transition from BI code to BA in the official mode contained two utterances, namely speech numbered (1) and (2). Intensive contact between two or more languages in a situation that has a bilingual environment such as in Indonesian society and in this case Bangil City can lead to code switching and code mixing. In this study, it can be concluded that in the speeches of ethnic Arab descendants, they often do switched code and mixed code.

(C) 2020, Wegig Prasasti

This is an open access article under CC-BY license (c) (i) (O)

\begin{tabular}{l}
\hline How to Cite:Prasasti, W. (2020). Tuturan Bahasa Indonesia Masyrakat Etnik Keturunan Arab \\
di Bangil. JURNAL SATWIKA, 4(2), 140-149. doi: \\
https://doi/org/10.22219/SATWIKA.Vol4.No2.140-149.
\end{tabular}

\section{Pendahuluan}

Saat berkomunikasi antara satu dengan yang lain, hal yang perlu diperhatikan setiap individu adalah cara bertutur yang baik dan komunikatif. Dalam setiap komunikasi manusia saling menyampaikan informasi berupa pikiran, gagasan, maksud, perasaan, maupun emosi secara langsung. Maka dari itu, dalam setiap proses komunikasi ada yang disebut peristiwa tutur dan tindak tutur.

Peristiwa tutur adalah berlangsungnya interaksi linguistik dalam satu bentuk ujaran atau lebih yang melibatkan dua pihak, yakni penutur dan pendengar (Wardhaugh, 2006:254). Peristiwa tutur merupakan peristiwa sosial karena menyangkut pihakpihak yang bertutur dalam satu situasi dan tempat tertentu. Jika peristiwa tutur lebih dilihat pada tujuan peristiwanya, maka tindak tutur dilihat pada makna atau arti tindakan dalam tuturannya. Tindak tutur dan peristiwa tutur merupakan dua gejala yang terdapat pada satu proses, yaitu proses komunikasi.

Sebagai sebuah langue bahasa mempunyai sistem dan subsistem yang dipahami oleh semua penutur bahasa tersebut. Akan tetapi, karena penutur bahasa tersebut berada dalam masyarakat tutur, dan bukan merupakan kumpulan manusia yang homogen, maka wujud bahasa yang konkret atau parole menjadi tidak seragam. Bahasa menjadi beragam dan bervariasi (Verhaar, 2010:4). Terjadinya keragaman ini bukan hanya disebabkan oleh penuturnya yang tidak homogen, tetapi juga karena kegiatan interaksi sosial yang mereka lakukan sangat beragam.

Setiap

kegiatan

komunikasi menyebabkan terjadinya keragaman bahasa. Keragaman ini akan semakin bertambah jika bahasa tersebut digunakan oleh penutur yang sangat banyak, serta wilayah yang sangat luas. Chaer dan Agustina (2010: 61), menyebutkan bahwa variasi bahasa atau ragam bahasa terjadi akibat dari adanya keragaman sosial dan keragaman fungsi bahasa. Variasi bahasa ada untuk memenuhi fungsinya sebagai alat interaksi dalam kegiatan masyarakat yang beraneka ragam.

Indonesia merupakan negara yang luas, terdiri dari 1.340 suku bangsa dan 300 kelompok etnik yang tersebar di seluruh Indonesia. Hal tersebut membuat Indonesia kaya akan budaya dan variasi bahasa. Dapat dipastikan bahwa tiap etnik yang ada di Indonesia akan memiliki tuturan yang berbeda antara satu sama lain.

Kota Bangil merupakan salah satu kota kecil yang berada di Kabupaten Pasuruan. Terhitung mulai tanggal 28 Juni 2016 kota yang dijuluki sebagai "Bang Kodir" atau "Bangil Kota Bordir" ini telah resmi menjadi Ibu Kota Kabupaten Pasuruan. Sesuai yang tertuang di Peraturan Pemerintah (PP) No 26 Tahun 2016 tersebut sekaligus akan ditindaklanjuti dengan pemindahan ibu kota dari Kota Pasuruan ke Kota Bangil. Kota Bangil memiliki ragam etnik yang tersebar di setiap wilayah, ada Jawa, Madura, Cina, India, dan Arab.

Kota Bangil memiliki daya tarik yang berbeda bagi para pendatang. Tercatat 
sebagian besar warga yang tinggal di Kota Bangil bukanlah keturunan asli orang Jawa Timur. Mereka adalah pendatang dari daerah dan negara lain yang kemudian menentap dan menjadi warga Bangil. Keturunan dari mereka menikah dengan sesama ras mereka yang kemudian berkembang menjadi kelompok manusia yang memiliki etnik tersendiri.

Di Kota Bangil terdapat daerah dengan komunitas tersendiri. Misalnya, di Kauman tempat tersebut 'khusus' ditempati oleh warga keturunan etnik Arab, India, dan Pakistan. Mereka juga memiliki bisnis yang dominan dimiliki oleh warga mereka sendiri. Misalnya, mereka menjual bibit parfum, oleh-oleh khas untuk haji dan umroh, serta masakan khas Arab. Meski begitu, mereka hidup berdampingan dengan harmonis bersama warga pribumi. Maka dari itu, tutur kata yang dituturkan warga etnik keturunan Arab juga dipengaruhi oleh pribumi di Kota Bangil.

Literatur komunikasi lintas budaya banyak membahas nilai-nilai Arab, yakni ramah, senioritas, dan spiritualis. Mereka juga dikenal bangga dengan budaya mereka dan tidak larut dengan budaya lain (Mulyana, 2016: 148). Etnik Arab memiliki tempat tersendiri di Kota Bangil. Bangil juga dekat dengan stereotipe orang Arab. Oleh karena itu, banyak sekali pendatang dari Arab untuk menetap di Bangil dan bahkan mereka sampai memiliki keturunan yang telah tersebar di seluruh wilayah Bangil. Etnik Arab sendiri tentu akan memiliki tuturan khas yang menunjukkan identitas mereka. Gaya komunikasi orang Arab termasuk gaya komunikasi konteksmenengah, yakni tidak suka bertele-tele dan basa-basi. Tuturan etnik keturunan Arab masuk dalam peristiwa campur kode dan alih kode. Mereka sering bertutur dengan langsung dua bahasa, yaitu bahasa Arab dan bahasa Indonesia baik dengan sengaja maupun tidak. Karenanya penelitian ini bertujuan mengetahui tuturan yang digunakan masyarakat Etnik Arab di Kota Bangil.
Adapun beberapa penelitian sebelumnya yang berhubungan dengan tuturan bahasa Indonesia etnik keturunan Arab dilakukan oleh Sutarsih (2016), berjudul "Campur Kode dari Bahasa ke dalam Bahasa Indonesia Tuturan Masyarakat Keturunan Arab di Kampung Pekojan Semarang". Penelitian tersebut menyimpulkan bahwa masyarakat berkomunikasi dengan melakukan campur kode antara bahasa Arab, Indonesia, dan Betawi. Campur kode tersebut merupakan interaksi masyarakat etnik Arab dengan warga sekitar.

Penelitian lain yang sejenis yang ditulis oleh Sholihatin (2008), berjudul "Pemilihan Kode pada Masyarakat Keturunan Arab di Noyontaan, Kota Pekalongan: Kajian Sosiolinguistik". Dari penelitian tersebut ditemukan bahwa (1) pemilihan kode bahasa dalam masyarakat tutur di Noyontaan terpola berdasarkan ranah pemakaian bahasa dalam interaksi sosial, (2) variasi kode bahasa yang merupakan repertoar bahasa masyarakat tutur di Noyontaan, Kota Pekalongan mencakup variasi tunggal bahasa, variasi alih kode, dan variasi campur kode. Hal tersebut juga dipengaruhi oleh interaksi dan komunikasi dengan masyarakat pribumi sehingga memengaruhi cara tuturan masyarakat keturunan Arab.

Berdasarkan dari kedua penelitian sebelumnya, diketahui bahwa penelitina ini memiliki persamaan dengan penelitian tentang masyarakat keturunan Arab dalam bertutur. Masyarakat menggunakan bahasa asli, alih kode, dan campur kode. Hal tersebut disebabkan oleh lingkungan yang memengaruhi bagaimana cara bertutur dengan bahasa daerah masing-masing. Dari kedua penelitian tersebut dapat disimpulkan bahwa masyarakat Arab cenderung melakukan alih kode dan campur kode dengan bahasa masyarakat asli sehari-hari, sehingga bahasa yang muncul adalah ertautan antara bahasa Arab dengan bahasa Indonesia atau daerah.

Perbedaan penelitian ini dengan penelitian terdahulu adalah lokasi yang digunakan, yakni di Kota Bangil. 
Masyarakat Bangil memiliki beragam etnik yang dapat memengaruhi cara bertutur hingga cara bersikap masyarakat Arab. Jika sebelumnya ditemukan pertautan antara bahasa Arab dan Indonesia, maka dalam penelitian ini ditemukan pertautan bahasa Arab dengan Jawa, Madura dan Indonesia. Cara berutur yang ditemukan adalah struktur bahasa yang tidak sesuai dengan kaidah Indonesia yang benar. Tuturan menggunakan bahasa Indonesia, namun dengan pola dari bahasa Jawa atau Madura.

\section{Metode}

Penelitian ini bertujuan untuk mengetahui tuturan yang digunakan oleh masyarakat etnik keturunan Arab di kota Bangil. Adapun pendekatan yang digunakan dalam penelitian ini adalah pendekatan kualitatif dengan metode penelitian etnografi. Creswell (2015: 942), menyatakan penelitian etnografi merupakan salah satu strategi penelitian kualitatif yang di dalamnya peneliti menyelidiki suatu kelompok kebudayaan di lingkungan alamiah dalam periode waktu yang cukup lama dalam pengumpulan data utama, data observasi, dan data wawancara.

Metode penelitian yang digunakan adalah melalui wawancara tidak langsung. Peneliti mengamati sekelompok masyarakat yang kemudian mendengarkan bagaimana acara mereka beriteraksi. Tidak ada unsur kesengajaan dengan tujuan penelitian agar hasil yang diperoleh menjadi lebih alami. Keabsahan data sangat penting dalam penelitian etnografi seperti ini.

Dalam penelitian ini, peneliti adalah pihak pengamat dalam penelitian ini. Peneliti yang datang dari luar kancah penelitian harus berbaur bahkan menyatukan dirinya dengan kancah penelitian tersebut. Oleh karena itu, kehadiran peneliti di dalam kancah penelitian secara (hampir) terusmenerus dalam waktu yang cukup panjang sangat penting artinya agar dapat menghayati apa yang sebenarnya terjadi di lapangan. Lokasi yang digunakan dalam penelitian ini adalah Kota Bangil yang terdiri dari daerah-daerah seperti Kauman,
Kalirejo, Kersikan. Karakteristik penduduk pada daerah-daerah tersebut merupakan lokasi yang tepat dalam penelitian yakni subjek penelitian adalah keturunan etnik Arab. Data dalam penelitian meliputi berbagai macam tuturan dalam praktik berbahasa Indonesia, Jawa, dan Arab yang berbentuk lisan. Sumber data pada penelitian ini bersifat lokasional, sebab sumber data itu merupakan tempat asal muasalnya.

Tabel 1 Tahapan Penelitian

\begin{tabular}{|c|c|c|}
\hline No & Tahap Penelitian & Penelitian \\
\hline 1. & $\begin{array}{l}\text { Menemukan } \\
\text { karakterisasi } \\
\text { sumber penelitian }\end{array}$ & 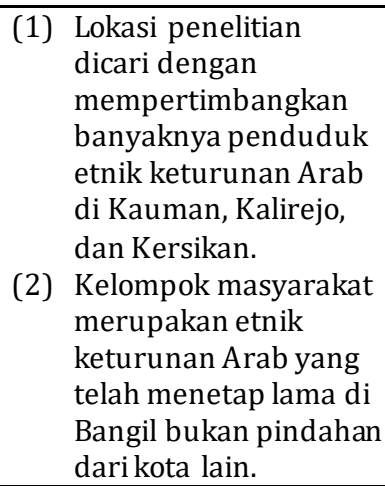 \\
\hline 2. & Observasi & 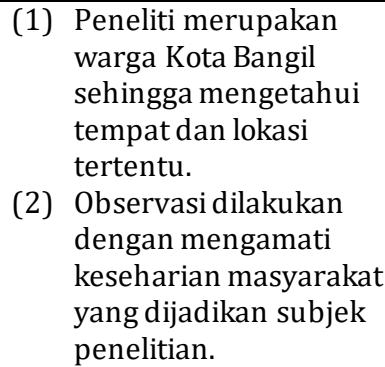 \\
\hline 3. & Sumber Data & 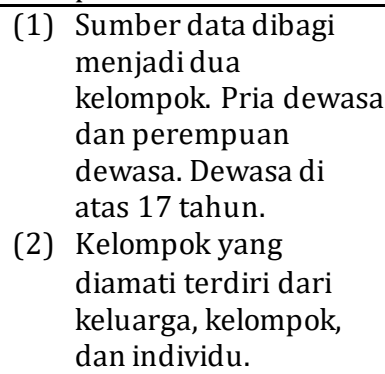 \\
\hline 4. & $\begin{array}{l}\text { Wawancara tidak } \\
\text { langsung }\end{array}$ & $\begin{array}{l}\text { (1) } \begin{array}{l}\text { Wawancara dilakukan } \\
\text { dengan mengamati }\end{array} \\
\text { situasi resmi dan tidak } \\
\text { resmi. } \\
\text { (2) } \\
\text { Tidak ada unsur } \\
\text { kesengajaan untuk } \\
\text { meneliti sehingga } \\
\text { masyarakat dapat } \\
\text { lebih natural. }\end{array}$ \\
\hline 5. & Interpretasi & $\begin{array}{ll}\text { (1) } & \text { Menganalisis dan } \\
\text { menyajikan hasil } \\
\text { tuturan etnik Arab. } \\
\text { (2) } \\
\text { Melakukan penarikan } \\
\text { kesimpulan. }\end{array}$ \\
\hline
\end{tabular}


Penelitian dengan kajian ilmu etnografi digunakan untuk memahami suatu masyarakat dengan keunikan mereka masing-masing. Hal tersebut dapat tampak dari budaya yang terwujud dalam tuturan mereka sehari-hari. Suharsaputra (2012: 235), menyatakan bahwa penelitian etnografi juga meneliti mengenai perkembangan budaya. Budaya yang dibawa oleh sebuah masyarakat tertentu akan memengaruhi masyarakat lain secara tidak langsung.

\section{Hasil dan Pembahasan}

\subsection{Wujud Alih Kode Tuturan Masyarakat Etnik Keturunan Arab}

Masyarakat keturunan etnik Arab umumnya tergolong masyarakat dwibahasa. Mereka menguasai bahasa pertama (B1) bahasa daerah dan bahasa kedua (B2) bahasa Arab. Pranowo (2015:103) menyatakan bahwa kedwibahasaan adalah pemakaian dua bahasa secara bergantian baik secara produktif maupun reseptif oleh seorang individu maupun masyarakat. Kasus di sini adalah dalam berkomunikasi masyarakat etnik keturunan Arab terkadang melakukan alih kode. Alih kode merupakan gejala peralihan pemakaian bahasa karena berubahnya situasi. Alih kode bukan hanya terjadi antarbahasa, tetapi dapat juga terjadi antara ragam-ragam atau gaya-gaya yang terdapat dalam satu bahasa.

Ragam yang dimaksud dalam penelitian ini adalah suasana maupun gaya bahasa yang terjadi ketika suatu peristiwa tutur berlangsung. Pada penelitian ini, ragam bahasa yang digunakan ketika terjadi peralihan kode dari BI ke BA adalah dua tuturan dalam ragam resmi. Pada penelitian ini, peralihan kode BI ke BA dalam ragam resmi terdapat dua tuturan, yaitu tuturan yang diberi nomor (1) dan (2).

(1) Apabila ada salah kata mohon dimaafkan. Allahumuwaafiq ilaa Aqwaamit thoriq. Wassalamualaikum warahmatullahi wabarakatuh.

(Apabila ada salah kata mohon dimaafkan. Allah selalu menunjukkan ke jalan yang lurus. Wassalamuealaikum warahmatullahi wabarakatuh)

Penutur pada tuturan (1) adalah seorang muballigh terkenal di daerah Bangil yang sedang memberikan ceramah di sebuah acara pernikahan dan yang sedang mendengarkan ceramah tersebut terdiri dari masyarakat keturunan Arab dan masyarakat etnis lainnya, yaitu Jawa. Dalam tuturannya terlihat bahwa terjadi peralihan bahasa dari BI ke BA dalam tataran peralihan kalimat. Awalnya, muballigh tersebut menggunakan kalimat BI "Apabila ada salah kata mohon dimaafkan", kemudian tuturan beralih ke kalimat BA "Allahu muwaafiq ilaa aqwaamit thoriq. Wassalamu "alaikum warahmatullahi wabarakatuh."

Ragam bahasa yang digunakan dalam peristiwa tutur ini adalah ragam fusha (tinggi). Ragam fusha selalu digunakan dalam berbagai situasi resmi.

(2) Dalam istilah arabnya, alwaqtu kas saif.

(Dalam istilah arabnya, waktu adalah pedang.)

Tuturan pada peristiwa tutur (2) dituturkan oleh muballigh yang lain dalam khutbah Jumat. Medium pembicaraan tuturan tersebut melalui medium lisan, pidato. Pada peristiwa tersebut terlihat bahwa terjadi peralihan dalam tataran klausa dari BI ke BA. Pada awalnya penutur berkata dalam BI "Dalam istilah Arabnya", kemudian beralih ke dalam BA "alwaqtu kassaif". Ragam resmi dalam peristiwa tutur tersebut terjadi dalam sebuah pidato di hadapan para sidang sholat Jumat. Peralihan kode dari BI ke BA dalam penelitian ini terjadi karena beberapa faktor yaitu, dua peristiwa tutur yang disebabkan faktor ingin menunjukkan identitas diri sebagai golongan nahdliyyin dan faktor penutur yang terpelajar.

Pada penelitian ini, ragam bahasa yang digunakan ketika terjadi peralihan kode dari BA ke BI adalah dua tuturan dalam ragam 
akrab. Pada peralihan kode dari BA ke BI ditemukan dua tuturan yang terjadi dalam ragam akrab, yaitu peristiwa tutur (3) dan (4).

Saat peristiwa tutur terjadi dalam keadaan resmi, maka bahasa yang digunakan adalah bahasa Arab yang resmi bersama dengan bahasa Indonesia. Tuturan tersebut umum diucapkan saat adanya ceramah agama. Ceramah tersebut dapat disampaikan saat kutbah Jumat, adanya pernikahan, atau peringatan hari besar agama Islam.

(3) Konteks: Seorang warga turunan etnik Arab bertemu dengan kerabatnya didepan rumah.

a) A : Assalamu'alaikum, ahlan wa sahlan ji. Keif?

(Assalamu'alaikum, Ji (haji). Bagaimana kabarnya?)

b) $\mathrm{B}$ : Wa'alaikumsalam, ahlan ane kheer. Ente keif?

(Wa'alaikumsalam, saya baik. Kamu bagaimana kabarnya?)

c) A : Alhamdulillah kheer.

(Alhamdulillah baik)

d) B : Eh, gimana keluarga?

e) A : Alhamdullilah, sehat semua.

Peristiwa tutur (3) tersebut terjadi di depan rumah ketika seorang warga keturunan etnik Arab (A) bertemu dengan kerabatnya yang merupakan tetangga dan sudah pergi haji, oleh karena itu dipanggil dengan sebutan 'ji' atau haji (B), keduanya adalah masyarakat keturunan Arab yang sama-sama menguasai BA. Percakapan tersebut terjadi pada pukul 16.00 WIB. Penutur dan mitra tutur dalam peristiwa tutur memiliki hubungan kerabat. Oleh karena itu, peristiwa tutur tersebut terjadi dalam ragam akrab.

Pada tuturan (a) terlihat bahwa (A) memulai percakapan dengan menggunakan Assalamuealaikum. Salam ini lazim digunakan para muslim ketika mengawali percakapan. Kemudian (A) melanjutkan dengan bertanya kabar kepada B dengan menggunakan kalimat BA
Assalamu'alaikum, ahlan wa sahlan ji. Keif?. (B) menjawab salam dari (A) dengan kalimat yang setara dan berbalik menanyakan keadaan (A) menggunakan kalimat BA Wa"alaikumsalam, ahlan ane kheer. Ente keif? Mereka bertukar kabar menggunakan kalimat-kalimat BA karena percakapan tersebut terjadi dalam ragam akrab (a), (b), dan (c). Setelahnya, percakapan beralih topik mengenai kabar tentang keluarga (A) menggunakan kalimatkalimat BI (d) dan (e).

Berdasarkan tuturan tersebut terjadi peralihan dari bahasa Arab ke bahasa Indonesia dengan pola bahasa Jawa. Ragam tidak resmi tersebut dapat terlihat pada tuturan (d). Penutur B tidak perlu menanyakan dengan lengkap seperti "Bagaimana keadaan keluarga Anda saat ini?" sebab sudah satu konteks maka pendengar pun paham apa yang ingin disampaikan oleh petutur. Tidak perlu lagi dijelaskan sebab sudah dalam satu situasi.

Pola kalimat yang menunjukkan sapaan haji juga dipengaruhi oleh kebiasaan masyarakat daerah Madura. Jika ada salah seorang lelaki dewasa sudah berangkat haji maka akan disapa dengan sebutan 'Ji'. Sebutan tersebut lazim digunakan dalam masayarakat di Bangil. Penampilan fisik yang juga didukung oleh gelar tersebut, umumnya mereka mempakai kopyah putih dan berjenggot.

(4) Bib, kam? Lima ribu dapet dua ya. (Pak, berapa? Lima ribu dapet dua ya.)

Pada percakapan (4) terjadi dalam ranah pekerjaan ketika seorang pembeli masyarakat keturunan Arab menawar dagangan penjual. Terlihat dalam percakapan tersebut bahwa terjadi peralihan kode dari BA ke BI. Peristiwa tutur tersebut terjadi dalam ragam akrab karena situasi yang terjadi antara penutur dan mitra tutur adalah situasi keakraban.

Peristiwa tersebut terjadi saat melakukan proses jual beli di sebuah toko kelontong. Pembelinya adalah seorang pria dewasa dan begitu pula sebaliknya dengan 
penjual. Si pembeli atau penutur ingin menekankan kembali harga yang tertera pada barang tersebut. Sapaan "Bib" diujarkan bagi orang lelaki yang mencapai usia di atas 30 tahun.

\subsection{Wujud Campur Kode Tuturan Masyarakat Etnik Keturunan Arab}

Pembicaraan mengenai alih kode biasanya diikuti dengan pembicaraan mengenai campur kode. Kedua perstiwa yang lazim terjadi dalam masyarakat dwi bahasa ini memiliki kesamaan yang besar, sehingga seringkali sukar dibedakan. Kesamaan antara alih kode dan campur kode adalah digunakannya dua bahasa atau lebih, atau dua varian dari sebuah bahasa dalam satu masyarakat tutur. Sumarsono, (2012:202), menyatakan campur kode ini serupa dengan apa yang disebut interferensi dari satu bahasa ke bahasa lain.

Banyak ragam pendapat mengenai beda keduanya. Jika dalam alih kode setiap bahasa atau ragam bahasa yang digunakan itu masih memiliki fungsi otonomi masingmasing dilakukan dengan sadar dan karena sebab-sebab tertentu, sedangkan dalam campur kode ada sebuah kode yang digunakan dan memiliki fungsi dan keotonomiannya. Campur kode (codemixing) terjadi apabila seorang penutur menggunakan suatu bahasa secara dominan mendukung suatu tuturan disisipi dengan unsur bahasa lainnya. Hal ini biasanya berhubungan dengan karakteristk penutur, seperti latar belakang sosial, tingkat pendidikan, atau rasa keagamaan. Biasanya ciri menonjolnya berupa kesantaian atau situasi informal. Namun, bisa terjadi karena keterbatasan bahasa, ungkapan dalam bahasa tersebut tidak ada padanannya, sehingga ada keterpaksaan menggunakan bahasa lain, walaupun hanya mendukung satu fungsi.

Ragam yang dimaksud dalam penelitian ini adalah suasana maupun gaya bahasa yang terjadi ketika suatu peristiwa tutur berlangsung. Pada penelitian ini, ragam bahasa yang digunakan ketika terjadi campur kode BA dalam BI adalah sebuah tuturan dalam ragam resmi, tiga tuturan dalam ragam usaha, dan tiga tuturan dalam ragam akrab. Peristiwa tutur yang terjadi dalam ragam resmi pada penilitian ini, terdapat sebuah tuturan. Berikut adalah rinciannya.

\section{(5) Ilaahinnaas, Tuhannya manusia.}

Peristiwa tutur (5) tersebut dituturkan oleh seorang muballigh dari masyarakat etnik keturunan Arab ketika sedang mengisi ceramah dalam kutbah Jumat. Medium tuturan tersebut adalah medium lisan panggung. Ragam yang dipakai dalam khutbah Jumat tersebut adalah ragam resmi.

Ragam resmi seperti halnya peristiwa tutur tersebut dapat dijumpai saat ada kegiatan keagamaan. Kegiatan tersebut dihadiri oleh masyarakat luas tidak hanya etnik keturunan Arab saja tetapi Jawa dan Madura. Maka dari itu, ujaran yang digunakan dapat dipahami seluruh lapisan masyarakat bukan hanya etnik tertentu.

Pada kelompok masyarakat luas, seorang penutur akan mengutamakan penggunaan bahasa yang dipahami oleh pendengar di sekitarnya. Meski akan terlihat 'berwibawa' dengan menggunakan bahasa asing dalam hal ini bahasa Arab, tetapi jika pendengar tidak ada yang memahami secara baik maka juga tidak akan menghasilkan informasi yang tersampaikan atau tidak komunikatif.

Penggunaan bahasa yang paling baik adalah saat kedua penutur memahami bahasa yang disampaikan satu sama lain. Meski adanya perbedaan dalam hal pemilihan kata atau dialek, tetapi jika informasi disampaikan bisa tepat maka tidak akan menjadi sebuah masalah. Seperti halnya yang disampaikan oleh Wardhaugh dan Fuller (2015:54), bahasa adalah milik individu dan milik sosial. Menyikapi dari hal tersebut, peristiwa tutur antara individu tertentu dan kelompok individu tertentu akan berperilaku linguistik seperti individu lain. Mereka mungkin dikatakan berbicara dalam bahasa yang sama atau dialek yang sama atau menggunakan kode yang sama. 
Pada contoh berikutnya (6) mengenai tuturan akrab dua orang teman ketika hendak memutuskan mereka akan pergi ke mana.

A : shobahulkher ya ukhty, pagi ni kita jadi jalan ila suuq aw dukkaan?

(pagi yang indah wahai saudaraku, pagi ini kita jadi jalan ke pasar atau ke toko?

B : kholaas ila suuq faqot, aku mau beli sayur buat ghodaa'

(sudahlah ke pasar saja, aku mau beli sayur buat makan siang)

Peristiwa tutur (6) tersebut dituturkan oleh dua orang wanita berusia sekitar tiga puluhan. Mereka berbincang mengenai ke mana tujuan mereka. Di sini mereka sesekali menggunakan tuturan bahasa Indonesia (BI) yang disisipkan di antara tuturan bahasa Arab mereka (BA). Hal tersebut tidak menjadi masalah dikarenakan keduanya merupakan sama-sama etnik keturunan Arab dan memahami bahasa satu sama lain.

Perubahan wujud alih kode yang langsung dilakukan oleh penutur tentu dengan memperhatikan situasi dan kondisi. Kondisi lawan biacara adalah sesame etnik keturunan Arab maka tidak akan menjadi sulit jika langsung menngunakan bahas Arab. Pemahaman antara kedua penutur tersebut akan menghasilkan informasi yang dapat diterima oleh keduanya. Holmes (2008:235), menyatakan bahwa penggabungan informasi tentang cara orangorang dari kelompok sosial yang berbeda berbicara dengan informasi tentang cara orang berbicara dalam konteks yang berbeda, jelas fitur itu kelas sosial dan gaya kontekstual berinteraksi.

Contoh berikutnya mengenai konteks ada seorang masyarakat keturunan Arab menyampaikan pesan kepada adiknya.

A : Bib, dicari abah.

(Dik, dicari ayah.)

B : Fein?

(Di mana?)

A : Baet.

(Di rumah)
Peristiwa tutur (7) tersebut terjadi dalam ragam akrab antara kakak beradik masyarakat keturunan Arab. Penutur (A) memberikan informasi kepada adiknya bahwa adiknya (B) sedang dicari ayahnya menggunakan kalimat "Bib, dicari Abah." Hubungan kerabat sebagai kakak-adik menciptakan suasana akrab yang terjadi dalam peristiwa tutur tersebut. Kalimat tersebut terindikasi adanya campur kode dengan adanya kata "Bib" yang menunjuk kepada seseorang yang dihormati atau sesama masyarakat keturunan Arab dan kata abah (ayah). Fungsi utama percakapan tersebut menggunakan kalimat BI, namun karena faktor penutur dan mitra tutur yang sama-sama menguasai BA, mereka menyelipkan serpihan kata-kata BA.

Jika sebelumnya sapaan 'Bib' digunakan untuk menyapa seorang lelaki paruh baya, maka kasus di sini adalah sapaan untuk keluarga adik lelaki lebih tepatnya. Kata 'Bib' sudah bergeser makna menjadi generalisasi sebab secara umum orang yang memenuhi criteria akan disapa dengan panggilan "Bib". Tidak hanya masyarakat etnik keturunan Arab saja, bahkan orang Jawa yang sudah berkawan lama dengan masyarakat etnik keturunan Arab pun akan disapa dengan "Bib".

Percakapan dalam situasi akrab lebih banyak menggunakan bahasa Arab sebab petutur dan penutur sudah saling memahami satu sama lain. Tidak perlu membuat pola kalimat yang terlalu panjang dan lebar jika keduanya sudah memahami. Konteks keakraban dalam keluarga juga memicu pola percakapan yang sangat sederhana, namun dipahami oleh lawan bicara.

Dari peristiwa tutur tersebut masyarakat etnik keturunan Arab cenderung melakukan campur kode saat melakukan percakapan dengan konteks akrab. Konteks akrab sendiri memudahkan penutur etnik keturan Arab untuk melakukan percakapan dengan lawan bicara. Tingginya penutur yang melakukan campur kode antara bahasa Indonesia dengan bahasa Arab membuktikan bahwa lingkungan juga memengaruhi gaya 
percakapan. Hal tersebut tampak pada grafik 3.1 berikut.

Grafik 3.1 Penggunaan Bahasa Etnik Keturunan Arab di Kota Bangil

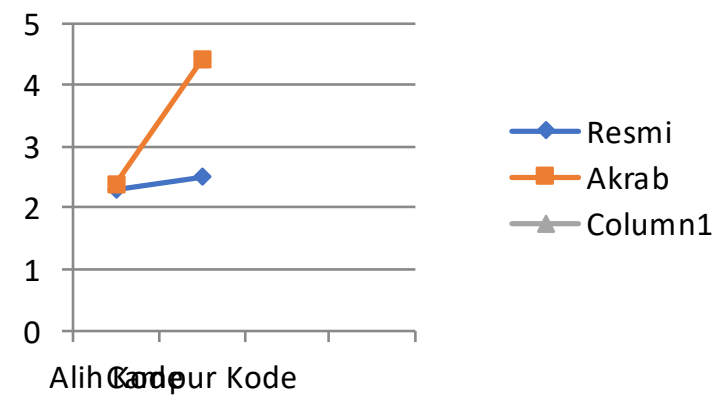

Berdasarkan grafik tersebut diketahui bahwa kecenderungan masyarakat etnik keturunan Arab menggunakan campur kode dalam situasi akrab dengan memperhatikan lawan bicara. Tingginya penggunaan campur kode dalam ranah akrab tidak hanya dilakukan sesama etnik keturunan Arab tetapi juga dengan masyarakat Jawa. Hal tersebut terjadi karena kebiasaan yang telah melekat dalam diri mereka. masyarakat Jawa juga ikut dipengaruhi penutur etnik keturunan Arab dalam hal komunikasi.

\section{Kesimpulan}

Kontak yang intensif antara dua bahasa atau lebih di dalam situasi yang memiliki lingkungan dwi bahasa seperti halnya di masyarakat Indonesia dan dalam kasus ini adalah Kota Bangil dapat menimbulkan alih kode dan campur kode. Alih kode adalah peristiwa peralihan dari satu kode ke kode lain dalam satu peristiwa tutur. Alih kode terjadi untuk menyesuaikan diri dengan peran tertentu atau dengan adanya tujuan tertentu. Campur kode terjadi apabila seorang penutur menggunakan suatu bahasa secara dominan mendukung suatu tuturan dan didiipi dengan unsur bahasa lain. Campur kode dapat terjadi tanpa adanya sesuatu dalam situasi berbahasa yang menuntut adanya percampuran bahasa, tetapi dapat juga terjadi karena faktor keakraban, kebiasaan, atau tidak adanya pandanan yang tepat.
Dalam penelitian tersebut dapat disimpulkan bahwa pada tuturan masyarakat etnik keturunan Arab cukup sering melakukan peristiwa alih kode dan campur kode. Mereka melakukan hal tersebut dari segi situasi dan kondisi. Dari contoh-contoh yang telah dikemukakan, masyarakat etnik keturunan Arab menggunakan peristiwa alih kode dalam tuturan formal, yakni ketika mereka mengisi sebuah ceramah ataupun menjadi pengisi materi ketika ibadah hari Jumat. Alih kode juga dapat terjadi dalam situasi nonformal atau keakraban. Hal tersebut terjadi ketika kedua penutur dari keturunan etnik yang sama, atau bisa juga ketika keduanya sama-sama mengerti apa yang sedang dituturkan pada saat itu. Dalam peristiwa campur kode yang dilakukan masyarakat etnik keturunan Arab dipertimbangkan dari segi situasi keakraban. Situasi hubungan yang sangat dekat sehingga memungkinkan kedua penutur untuk bertutut dengan campuran bahasa Arab dan bahasa Indonesia.

\section{Daftar Pustaka}

Chaer, A. dan Agustina, L. (2010). Sosiolinguistik Perkenalan Awal. Jakarta: Rineka Cipta.

Creswell, J. (2015). Riset Pendidikan. Terjemahan Helly Prajitno. 2015. Yogyakarta: Pustaka Pelajar.

Holmes, J. (2013). An Introductions to Sociolinguistics. New York: Routledge

Mulyana, D. (2016). Komunikasi Lintas Budaya. Bandung: Remaja Rosdakarya

Pranowo. (2015). Teori Belajar Bahasa. Pustaka Pelajar: Yogyakarta.

Sholihatin, A. (2008). Pemilihan Kode pada Masyarakat Keturunan Arab di Noyontaan, Kota Pekalongan: Kajian Sosiolinguistik. Tesis tidak diterbikan. Semarang: Universitas Diponegoro. 
Suharsaputra, U. (2012). Metode Penelitian:

Kuantitatif, Kualitatif, dan Tindakan.

Refika Aditama: Bandung.

Sumarsono. (2012). Sosiolinguistik. Pustaka

Pelajar: Yogyakarta.

Sutarsih. (2016). Campur Kode dari Bahasa ke dalam Bahasa Indonesia Tuturan

Masyarakat Keturunan Arab di Kampung Pekojan Semarang. Jurnal Ilmiah Kebahasaan dan Kesastraan Widyaparwa, 44 (2): 163-171.

Verhaar, J. W. M. (2010). Asas-Asas Linguistik Umum. Yogyakarta: Gadjah Mada University Press.

Wardhaugh, R. (2006). Sociolinguistics Fifith Edition. UK: Blackwell Publishing.

Wardhaugh, R. dan Fuller, J.M. (2015). An Introductions to Sociolingusitics Seventh Edition. West Sussex UK: John Wiley \& Sons, Inc. 